\title{
8. LATE EOCENE TO EARLY OLIGOCENE CALCAREOUS NANNOFOSSIL ASSEMBLAGES FROM SITES 699 AND 703, SUBANTARCTIC SOUTH ATLANTIC OCEAN ${ }^{1}$
}

\author{
Marina Madile ${ }^{2}$ and Simonetta Monechi ${ }^{3}$
}

\begin{abstract}
Calcareous nannofossil assemblages were studied from Sites 699 and 703, drilled during ODP Leg 114 to the west and east, respectively, of the Mid-Atlantic Ridge in the subantarctic South Atlantic Ocean. Recovery at the two sites consists of an almost continuous sequence of upper Eocene-lower Oligocene sediments. This study describes the calcareous nannofossil assemblages at the transition between the Eocene and Oligocene and correlates these assemblages with those described in lower latitude sections. Quantitative analyses were performed on several important taxa in order to improve the biostratigraphic resolution and permit some paleoenvironmental interpretations. Several discrepancies were noted between the two sites and between the Eocene and Oligocene assemblages. The Eocene assemblages show a great number of species and warmer water conditions; the early Oligocene assemblages are less diversified and are indicative of cooler conditions. The Eocene/Oligocene boundary was not defined by planktonic foraminifers because of the strong dissolution, poor recovery, and drilling disturbances. On the other hand, the calcareous nannofossil assemblage allowed recognition of the interval where the Eocene/ Oligocene boundary can possibly be placed.
\end{abstract}

\section{INTRODUCTION}

During Ocean Drilling Program (ODP) Leg 114 seven sites (698 through 704) were drilled in the subantarctic South Atlantic Ocean in the wide passageway that links the South Atlantic to the Weddell Sea basin (Fig. 1). The two major goals of Leg 114 were (1) to link regional tectonic events to the opening of the gateway that allowed antarctic cold waters to flow northward into the Argentine basin through the FalklandAgulhas Fracture Zone and (2) to reconstruct the history of climatic conditions from the Late Cretaceous to the Holocene.

This paper describes the calcareous nannofossil assemblages at the transition between the Eocene and the Oligocene and establishes correlations with lower latitude assemblages. An almost continuous sequence of upper Eocene-lower Oligocene sediments was recovered at only two of the seven sites drilled: Site 699, located west the Mid-Atlantic Ridge on the northeastern slope of the Northeast Georgia Rise $\left(51^{\circ} 32.537^{\prime} \mathrm{S}, 30^{\circ} 40.619^{\prime} \mathrm{W}\right)$, and Site 703 , located east of the ridge on the Meteor Rise $\left(47^{\circ} 03.042^{\prime} \mathrm{S}, 07^{\circ} 53.679^{\prime} \mathrm{E}\right)$. These sequences provide an excellent opportunity to study the biostratigraphic and biogeographic distribution of calcareous nannofossils at high latitudes. The upper Eocene-lower Oligocene sediments yield rich, but not diversified, calcareous nannofossil assemblages. Preservation ranges from moderate to poor, as a result of recrystallization and/or dissolution. Quantitative analyses were performed on several important taxa in order to improve biostratigraphic resolution and to permit some paleoenvironmental interpretations.

The distribution of calcareous nannofossils in the underlying and overlying sediments at these two sites, as well as at the other sites drilled during Leg 114, is presented by Crux (this volume).

\footnotetext{
${ }^{1}$ Ciesielski, P. F., Kristoffersen, Y., et al., 1991. Proc. ODP, Sci. Results, 114: College Station, TX (Ocean Drilling Program).

2 Dipartimento Scienze della Terra, Università Degli Studi di Firenze, Via La Pira 4, 50121 Firenze, Italy.

${ }^{3}$ Dipartimento di Geologia e Geofisica, Campus Universitario, Via Re David 4, 70125 Bari, Italy.
}

Stratigraphic and biogeographic studies of high-latitude calcareous nannofossil assemblages from Eocene-Oligocene sediments have been conducted by Edwards and PerchNielsen (1975), Wise and Wind (1977), Haq et al. (1977), Wise and Mostajo (1983), Wise (1983), and Wise et al. (1982) for Deep Sea Drilling Project (DSDP) Legs 36 and 71 and by Edwards and Perch-Nielsen (1975) for DSDP Leg 29.

For detailed regional paleoenvironmental information on Paleogene paleoclimatic and paleoceanographic conditions, the reader is referred to Keigwin and Corliss (1986), Krasheninnikov and Basov (1986), Boersma et al. (1987), Kennett $(1977,1978)$, and Nocchi et al. (this volume).

\section{METHODS}

Approximately one sample per each core section from Holes $699 \mathrm{~A}$ and $703 \mathrm{~A}$ was studied. There are missing intervals in both holes, especially in the upper Eocene, which are due to poor recovery or to soupy materials. Smear slides were made for each sample and were examined under a light microscope at a magnification of $1500 \times$. Abundances of individual nannofossil species are tabulated on the range charts in Tables 1 and 2. Estimates of the relative abundance of individual species in a given sample were made according to the following criteria:

$\mathrm{A}=$ Abundant: 1 specimen per 1 field of view.

$\mathrm{C}=$ Common: 1 specimen per 1 to 2 fields of view.

$\mathrm{F}=$ Few: 1 specimen per 2 to 10 fields of view.

$\mathrm{R}=$ Rare: 1 specimen per 10 to 100 fields view.

$\mathrm{RR}=$ Very rare: 1 specimen per more than 100 fields of view.

Reworking is rare in both holes and is characterized by Cretaceous and Paleocene specimens. A qualitative analysis of the state of preservation of the calcareous nannofossils was made using the following criteria:

$\mathrm{G}=$ Good: specimens exhibit no dissolution and/or overgrowth.

$\mathrm{M}=$ Moderate: specimens exhibit moderate dissolution and/or overgrowth.

$\mathrm{P}=$ Poor: specimens exhibit extreme dissolution and/or overgrowth.

Quantitative analyses were made on several important species using the method of Backman and Shackleton (1983) 


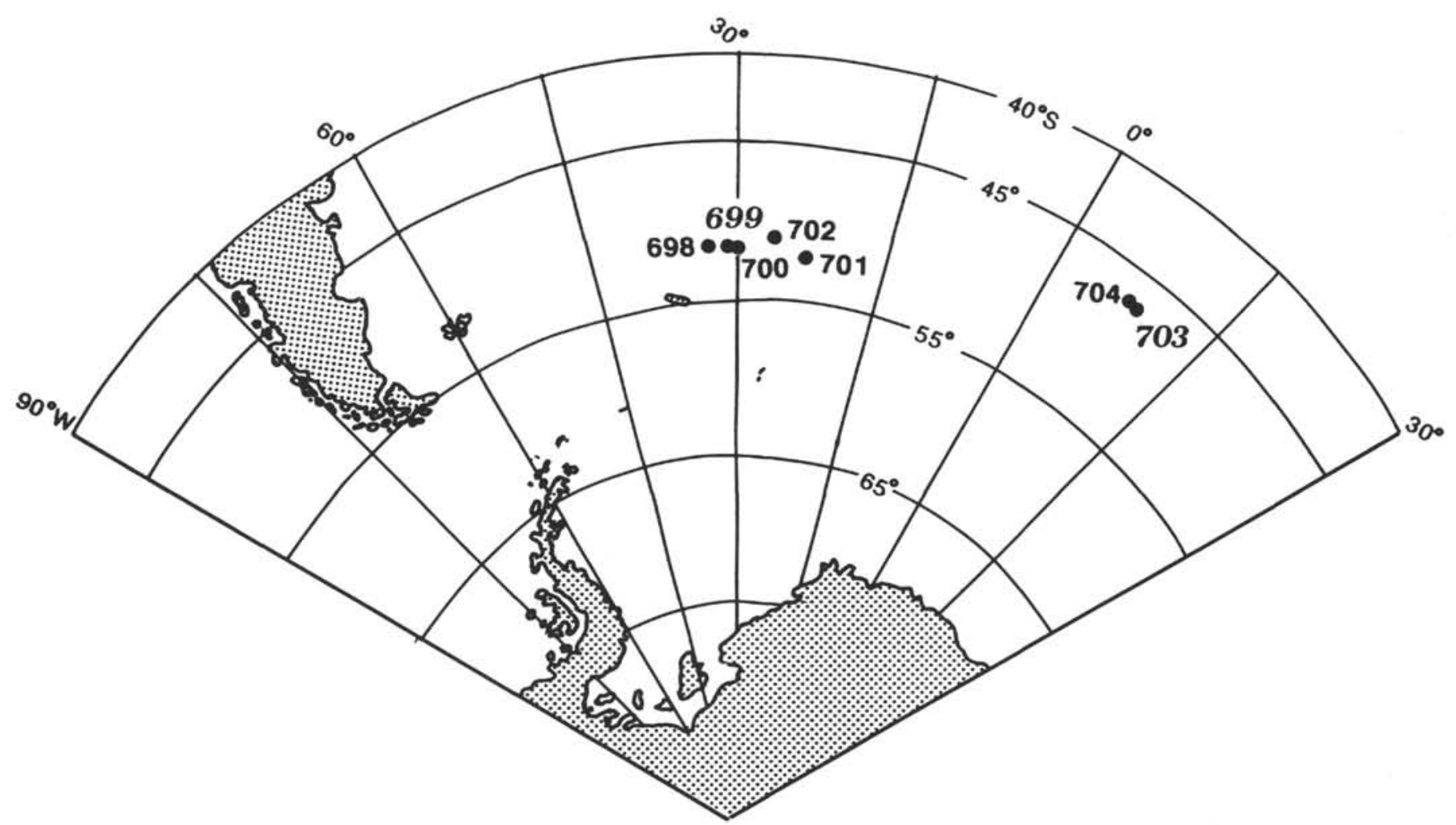

Figure 1. ODP Leg 114 site locations.

in which the abundance of each species is expressed as the number of specimens per square millimeter. The counts were performed on approximately 100 fields of view at a magnification of $1500 \times$. Only a few samples were examined with the scanning electron microscope (SEM); for taxonomic purposes, Moshkovitz's (1974) technique was used, which allows the study of the same specimen in both the light microscope and SEM.

The species considered in this report are listed alphabetically by species epithets in the Appendix; the bibliographic references of these species are given in Loeblich and Tappan (1966, 1968, 1969, 1970a, 1970b, 1971, 1973), van Heck (1979a, 1979b, 1980a, 1980b, 1981a, 1981b, 1982a, 1982b), and Steinmetz (1985a, 1985b, 1986a, 1986b, 1987a, 1987b).

\section{BIOSTRATIGRAPHY}

High-latitude nannofloral assemblages are less diversified than low-latitude assemblages; for this reason, fewer markers are available for the biostratigraphic resolution of high-latitude sections. The standard zonation of Martini (1971) and the low-latitude zonation of Bukry $(1973,1975)$ and Okada and Bukry (1980) are quite difficult to apply to the Leg 114 material, mainly because several low-latitude index forms are very rare or even absent. Instead, the biostratigraphic zonal scheme of Wise (1983), which was defined for the Falkland Plateau region, was used here, although a few zones could not be applied in this study because of different species concepts.

\section{Chiasmolithus oamaruensis Zone (= NP18)}

Definition. Interval from the first occurrence (FO) of Chiasmolithus oamaruensis and the FO of Isthmolithus recurvus.

Remarks. The Chiasmolithus oamaruensis Zone is present in both holes, but at Hole 703A the lower boundary was not reached. Very rare specimens of Discoaster barbadiensis, Discoaster saipanensis, and Bramletteius serraculoides are present only at Hole 699A. The assemblage is characterized mainly by $C$. oamaruensis, Cyclicargolithus floridanus, Dictyococcites bisectus, and Dictyococcites scrippsae. Neococcolithes dubius (a cool-water species; Siesser, 1975) is present only in Hole 703A and disappears within this zone.

Age. Late Eocene.

\section{Isthmolithus recurvus Zone}

Definition. Interval from the FO of Isthmolithus recurvus to the FO of Reticulofenestra oamaruensis.

Remarks. This zone is present in both holes. The specimens of $I$. recurvus at Site 703 are smaller compared with those at Site 699 and very badly preserved. Strong overgrowth completely masks the central area.

Age. Late Eocene.

\section{Reticulofenestra oamaruensis Zone}

Definition. Interval from the FO of $R$. oamaruensis to the last occurrence (LO) of Discoaster saipanensis.

Remarks. Cribrocentrum reticulatum disappears within this zone in Sample 114-703A-15H-2, 130-131 cm, at a depth of $131.20 \mathrm{~m}$ below seafloor (mbsf). At Hole 699A the LO of $C$. reticulatum is just before the $\mathrm{FO}$ of $I$. recurvus. $C$. reticulatum is inferred to have an environmental preference for tropical to temperate conditions (Bukry, 1977) and has been found in sections from hemipelagic environments and open-ocean areas (Shafik, 1981). C. reticulatum was found at DSDP Site 511 (Wise, 1983), and its extinction level is before the LO of $D$. saipanensis. In low-latitude sections (Monechi, 1986; Coccioni et al., 1988; Premoli Silva et al., 1988) the extinction of C. reticulatum is also before the $\mathrm{LOs}$ of the disc-shaped discoasters, and it is correlated to the middle part of Zone P16 (Blow, 1969). Wei and Wise (in press) found that $C$. reticulatum becomes extinct earlier at high latitudes than at midlatitudes. In this study, the discrepancy between the two holes 


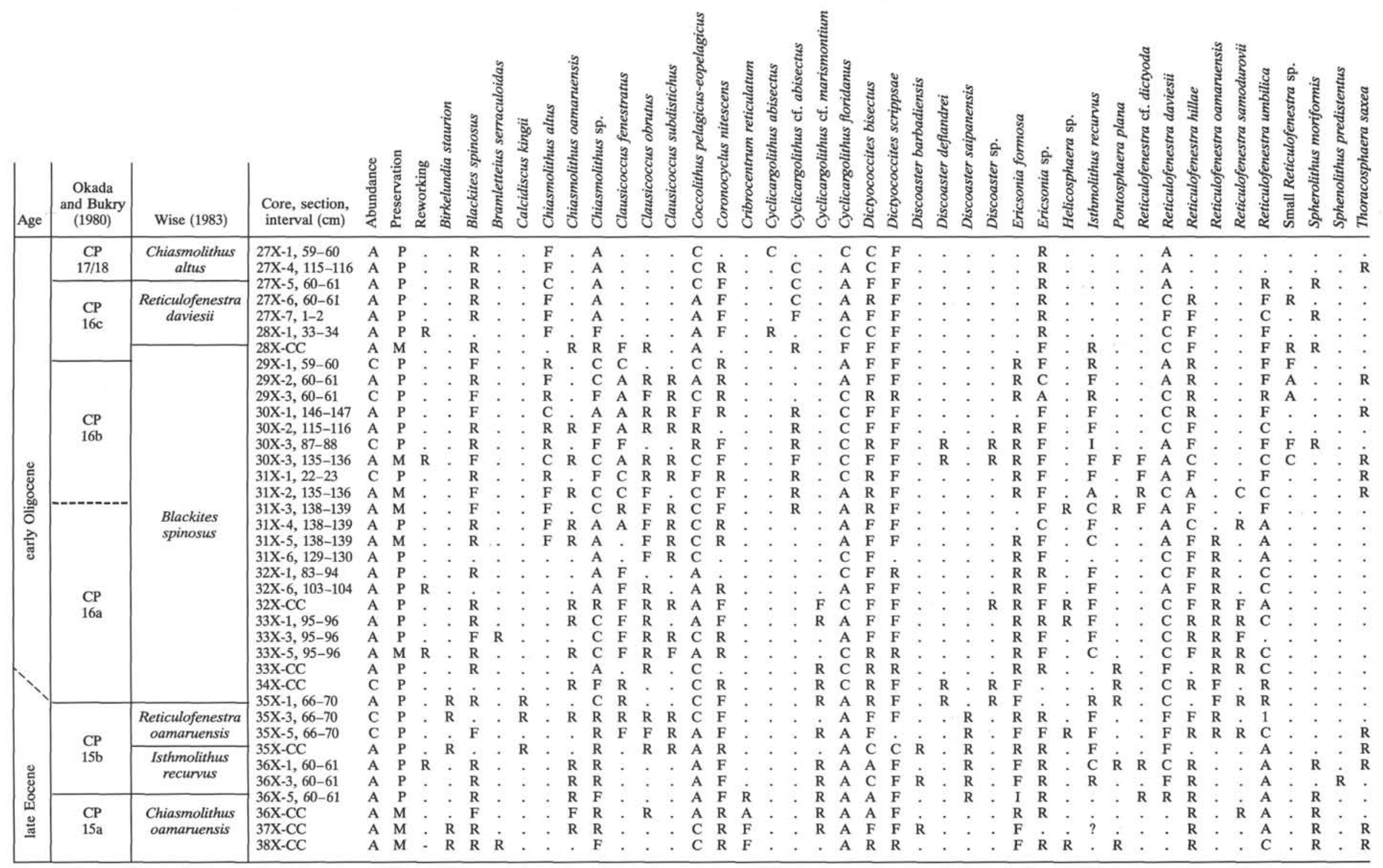

Note: Abundance: $\mathrm{A}=$ abundant $\mathrm{C}=$ common; $\mathrm{F}=$ few; $\mathrm{R}=$ rare; $\mathrm{RR}=$ very rare. Preservation: $\mathrm{M}=$ moderate; $\mathrm{P}=$ poor. ? = doubtful species identification. 


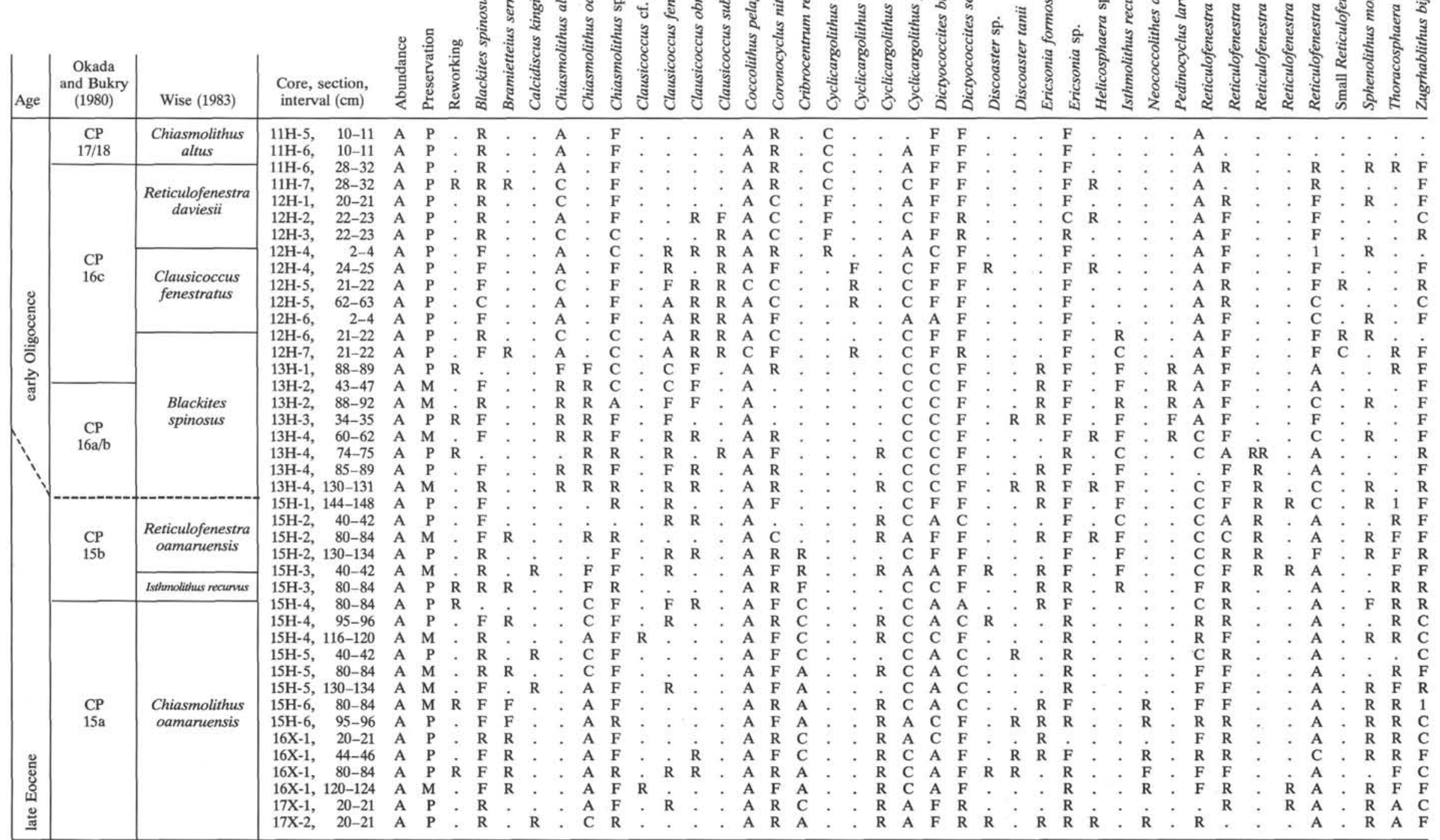

Note: Abundance: $\mathrm{A}=$ abundant; $\mathrm{C}=$ common; $\mathrm{F}=$ few; $\mathrm{R}=$ rare; $\mathrm{RR}=$ very rare. Preservation: $\mathrm{M}=$ moderate; $\mathrm{P}=$ poor. 
egarding the LO of $C$. reticulatum (at Site 699 it is before the $\checkmark$ O of I. recurvus) possibly could be explained either by Jaleoenvironmental problems or by the effects of strong lissolution at Site 699.

Age. Late Eocene.

\section{Blackites spinosus Zone}

Definition. Interval from the LO of $D$. saipanensis to the LO of $I$. recurvus.

Remarks. The lower boundary of this zone is not well lefined because of the scarcity of disc-shaped discoasters only rare to very rare $D$. barbadiensis and $D$. saipanensis Nere found in a few samples from Hole 699A); however, it zould be tentatively placed in Sample 114-699A-35X-3, 66-67 zm. In Hole 703A placement of the base is uncertain, because ff the absence of discoasters and a gap in the recovery. Within his zone several forms, such as Ericsonia formosa, $R$. oamauensis, and $C$. oamaruensis, disappear and Chiasmolithus zltus has its FO.

Age. Late Eocene-early Oligocene.

\section{Clausicoccus fenestratus Zone}

Definition. Interval from the LO of $I$. recurvus to the $\mathrm{LO}$ of Clausicoccus fenestratus.

Remarks. Wise (1983) used a very broad concept of $C$. fenestratus, which includes forms of Clausicoccus subdistichus, Clausicoccus obrutus, and C. fenestratus in this spezies, for the definition of this zone. In this study, the three species were separated on the basis of the different dimensions and the different structure of the central area. Only those forms with dimensions bigger than $6 \mu \mathrm{m}$ and that show well-defined holes in the central area were considered as $C$. fenestratus.

Age. Early Oligocene.

\section{Reticulofenestra daviesii Zone}

Definition. Interval from the last common occurrence of $C$. fenestratus to the LO of Reticulofenestra umbilica.

Remarks. The Reticulofenestra daviesii Zone is easily recognizable in Hole $703 \mathrm{~A}$; on the contrary, poor recovery in Hole 699A obscured the base of the zone. Within this zone, transitional forms between $C$. floridanus and Cyclicargolithus abisectus appear; these are listed on the distribution chart as Cyclicargolithus $\mathrm{cf}$. abisectus. The typical size of these forms is about $8 \mu \mathrm{m}$.

Age. Early Oligocene.

\section{Chiasmolithus altus Zone}

Definition. Interval from the LO of $R$. umbilica to the last common uphole occurrence of $C$. altus.

Remarks. Only the lower part of the zone was studied in both of the holes. The species diversity is very low; only 12 taxa were recognized. Reticulofenestrids and chiasmoliths dominate the assemblage.

\section{Site 699}

Site 699 is located on the northeastern slope of the Northeast Georgia Rise $\left(51^{\circ} 32.537^{\prime} \mathrm{S}, 30^{\circ} 40.619^{\prime} \mathrm{W}\right)$ in a water depth of $3716 \mathrm{~m}$. The section studied ranges in age from late Eocene, the Chiasmolithus oamaruensis Zone, to the late early Oligocene, the Chiasmolithus altus Zone. The approximately 100 $\mathrm{m}$ of sediments recovered includes a siliceous nannofossil ooze, which grades downward into nannofossil ooze, nannofossil chalk, and micritic chalk. The $\mathrm{CaCO}_{3}$ content drops sharply in the upper Eocene-lower Oligocene interval at about $300 \mathrm{mbsf}$. This reduction is due to a decreasing abundance of planktonic foraminifers (see Nocchi et al., this volume) and an increase in siliceous organisms. Nevertheless, calcareous nannofossils are always present and quite abundant. Unfortunately the recovery is quite poor: Core 114-699A-34X had no recovery and Cores 114-699A-25X through 114-699A-30X have a total recovery less than $50 \%$. For this reason the resolution of events is low at these core intervals.

The Eocene nannofossil assemblage is more diversified than that of the Oligocene, and it is characterized by approximately 38 taxa, although sphenoliths, discoasters, and helicosphaerids are sparse and pentaliths are absent. The assemblage consists mainly of reticulofenestrids, placoliths, and chiasmoliths. Only single specimens of Bramletteius serraculoides and Zygrhablithus bijugatus are present in two samples. The upper Eocene interval is characterized by a succession of extinctions and appearances (Fig. 2); the LO of the disc-shaped discoasters occurs at Sample 114-699A-35X-3, $66-70 \mathrm{~cm}$, at a depth of $319.60 \mathrm{mbsf}$. Core 114-699A-34X contains no sediments, and the assemblages from Cores 114-699A-33X and 114-699A-32X are the same except for the absence of discoasters. The upper part of the section studied is dominated by Cyclicargolithus, Chiasmolithus, and Reticulofenestra daviesii. The LO of Reticulofenestra umbilica defines the boundary between the Chiasmolithus altus Zone and the underlying $R$. daviesii Zone. The LOs of Clausicoccus fenestratus and Isthmolithus recurvus are coincident due to the poor recovery. Several fluctuations in abundance of $C$. fenestratus and the small Ericsonia-Clausicoccus were noted in the Blackites spinosus Zone. These fluctuations may be important for local correlation. It should be noted that Chiasmolithus oamaruensis disappears in the upper part of this zone. Reticulofenestra hillae is always less abundant than $R$. umbilica and becomes extinct just below it.

\section{Site 703}

Site 703 , located on the Meteor Rise $\left(47^{\circ} 03.042^{\prime} \mathrm{S}\right.$, $07^{\circ} 53.679^{\prime} \mathrm{E}$ ) in a water depth of $1807 \mathrm{~m}$, is between the Subtropical and the Antarctic convergences. This site received a significant biosiliceous input during the late Eocene and Oligocene. The interval studied from Hole 703A ranges in age from the late Eocene nannofossil Zone NP18 (Chiasmolithus oamaruensis Zone) up to the Chiasmolithus altus Zone. The thickness of the section is about $50 \mathrm{~m}$ (Cores 114-703A$17 \mathrm{X}$ to $114-703 \mathrm{~A}-11 \mathrm{H}$ ) and the dominant lithology is a foraminifer-bearing nannofossil ooze. Calcareous nannofossils are abundant throughout the section; preservation varies from moderate to poor.

The upper Eocene assemblage is characterized mainly by Cyclicargolithus floridanus, Cribrocentrum reticulatum, $R e$ ticulofenestra umbilica, Dictyococcites bisectus, and Dictyococcites scrippsae. Discoasters and helicosphaerids are absent. The succession of events observed in the upper Eocene includes the LO of Neococcolithes dubius and the FOs of Isthmolithus recurvus and Reticulofenestra oamaruensis. The LO of $C$. reticulatum is just above the FO of $I$. recurvus. No data were recovered from Core $114-703 \mathrm{~A}-14 \mathrm{H}$, because it consists entirely of soupy sediments. The overlying Core $114-703 \mathrm{~A}-13 \mathrm{H}$ contains the same assemblage with the addition of $C$. altus; several fluctuations in abundance of $I$. recurvus, Clausicoccus obrutus, and Clausicoccus fenestratus were also observed. Ericsonia formosa is quite rare and sporadic, but its extinction level appears to be at the top of Core 114-703A-13H (Fig. 3). C. oamaruensis, which is quite abundant in the upper Eocene, becomes quite rare and disappears at the same level as $E$. formosa. A succession of extinctions occurs in the upper Oligocene: $I$. recurvus in Sample 114-703A-12H-6, 21-22 cm, $C$. fenestratus in Sample 114-703A-12H-4, 2-4 cm, and $R$. umbilica and Reticulofenestra hillae in Sample 115-703A- 


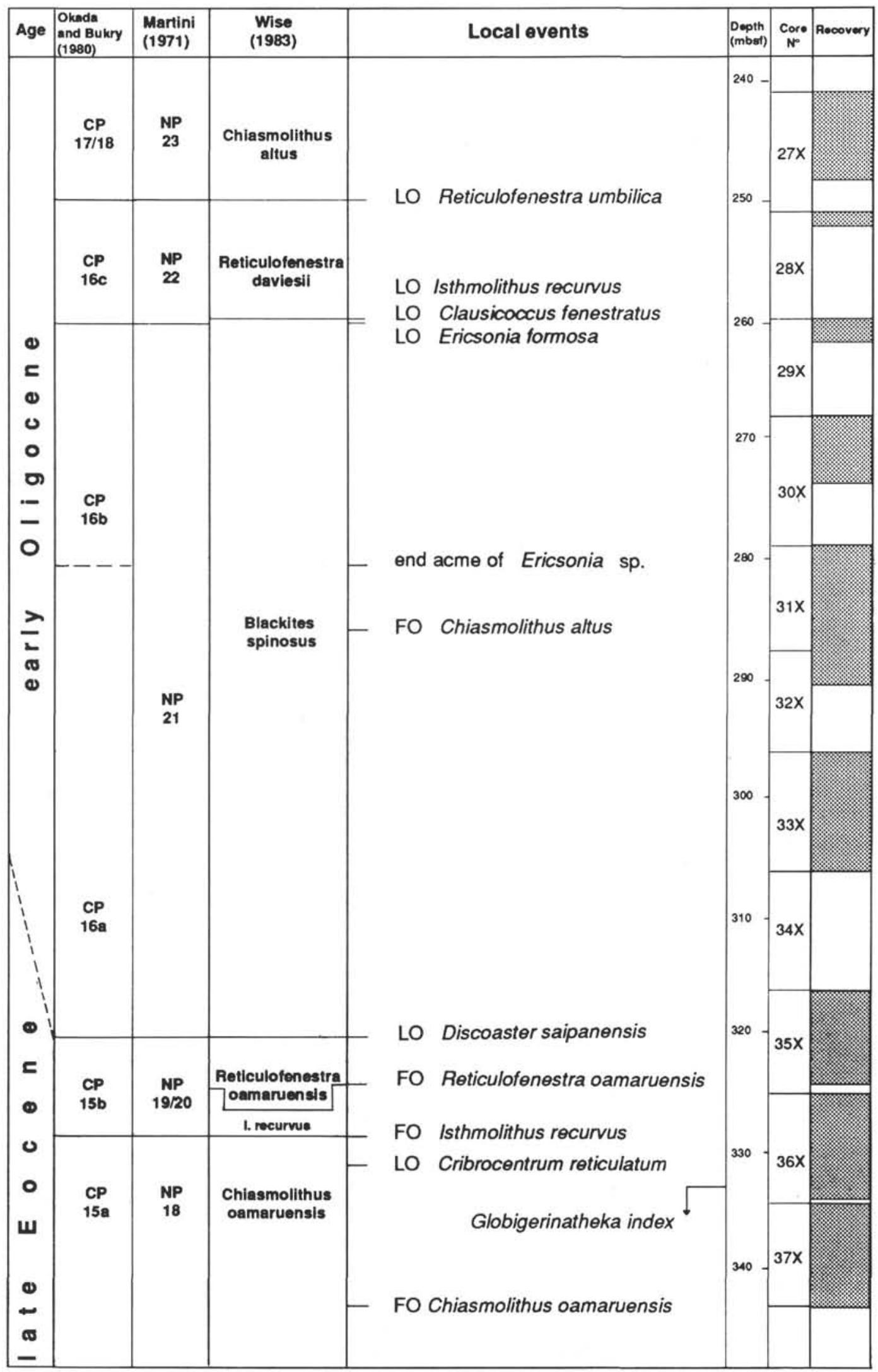

Figure 2. Major calcareous nannofossil events at Site 699 plotted against the zonations of Okada and Bukry (1980), Martini (1971), and Wise (1983). 


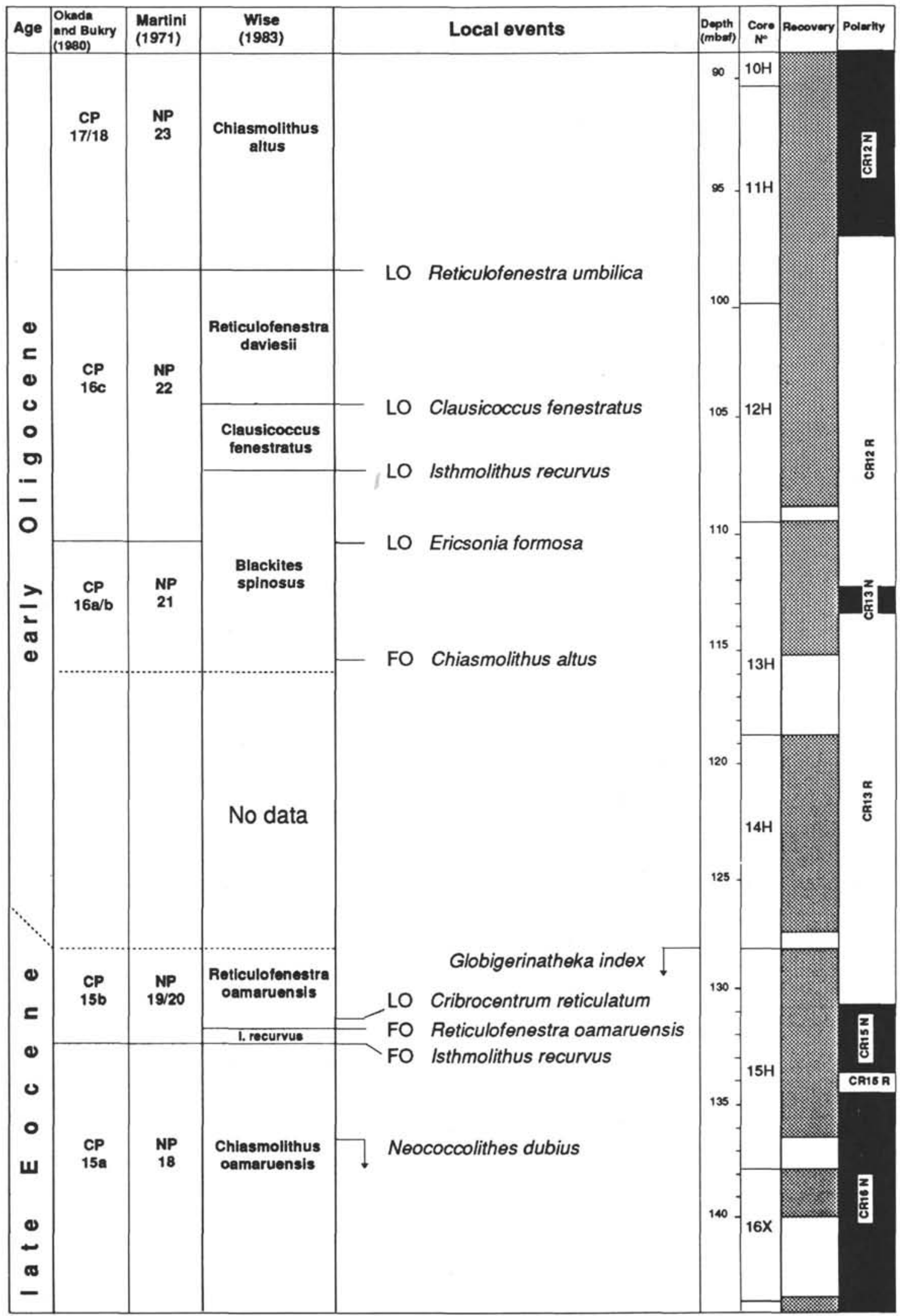

Figure 3. Major calcareous nannofossil events at Site 703 plotted against the zonations of Okada and Bukry (1980), Martini (1971), and Wise (1983) and the magnetostratigraphy (Ciesielski, Kristoffersen, et al., 1988). 
$11 \mathrm{H}-6,28-32 \mathrm{~cm}$. In the upper $10 \mathrm{~m}$ of the section studied, several fluctuations in the abundance of $C$. altus were also recognized. The number of species at the top of the sequence is very low; only 12 taxa were recognized in this interval.

\section{ABUNDANCE PATTERNS}

Detailed quantitative analyses of selected nannofossil species from the upper Eocene-lower Oligocene sediments of Sites 699 and 703 were performed in order to improve the biostratigraphic resolution, to gain some paleoenvironmental information, and to establish possible correlations between the biostratigraphy and magnetostratigraphy. The counting method used was that of Backman and Shackleton (1983; subsequently discussed by Backman, 1986). The plots presented in Figures 4 and 5 represent the abundances expressed as number of specimens counted per square millimeter unit area in the intervals investigated.

The abundance pattern of Reticulofenestra umbilica shows a general tendency toward progressive decline at both sites. This feature is quite evident at Site 703 whereas it is irregular at Site 699. It should be noted that the sharp decline is just above the FO of Isthmolithus recurvus. After this sharp decline several fluctuations were noted up to the extinction level. At Site 699 the increase and decrease of $R$. umbilica correlates well with the fluctuations of Chiasmolithus sp. and Ericsonia sp. One of the results of Backman's (1986) detailed study on the central opening/placolith length ratio of $R$. umbilica and Reticulofenestra hillae is that $R$. hillae may be considered an ecophenotype of $R$. umbilica; the author suggested, therefore, that the morphometric interrelationship between $R$. hillae and $R$. umbilica has a paleoenvironmental, rather than biostratigraphic, value. In particular, the increase of $R$. hillae, a reticulofenestrid species with a relatively smaller central opening size, might be linked to conditions of cooler temperature.

In the abundance plots (Figs. 4 and 5) the variations in abundance of $R$. hillae and $R$. umbilica are reported alongside each other. $R$. hillae is not very abundant in the Eocene, but increases in the lower Oligocene from Cores 114-699A-31X and 114-699A-32X, with a corresponding decrease of $R$. umbilica. Two recognizable peaks are at a core depth of about 280 mbsf. A cooler condition may also be suggested by the high abundance of $I$. recurvus and chiasmoliths. At the same depth, an increase in abundance of $C$. fenestratus was noted. At Site 703 the variations between the two morphovariants are not so clear as at Site 699, because of the lack of samples at the Eocene/Oligocene boundary; nevertheless, two peaks of $R$. hillae are present in Samples 114-703A-15H-2, 40-42 cm (upper Eocene), and 114-703A-13H-4, 74-75 cm. The two peaks correlate with an increase of $I$. recurvus, but there is no apparent correlation with $C$. fenestratus.

A tendency toward progressive decline has been noted in the abundance patterns of Dictyococcites bisectus and Dictyococcites scrippsae; the marked decrease in abundance occurs few samples above the extinction of disc-shaped discoasters. At Site 699 I. recurvus shows several fluctuations and has two peaks at the top of Cores 114-699A-31X and 114-699A-29X; it is always more abundant than at Site 703. Furthermore, in the distribution chart and abundance plots we distinguished Clausicoccus subdistichus, Clausicoccus obrutus, C. fenestratus, and Ericsonia spp.; in the latter we lumped together all the small Ericsonia-Clausicoccus in which we could not clearly recognize the central area.

C. subdistichus, C. obrutus, and Ericsonia spp. are not very abundant at Site 703 , and only $C$. fenestratus shows a high increase in abundance just below and above the LO of $I$. recurvus, which clearly correlates with an increase in abun-

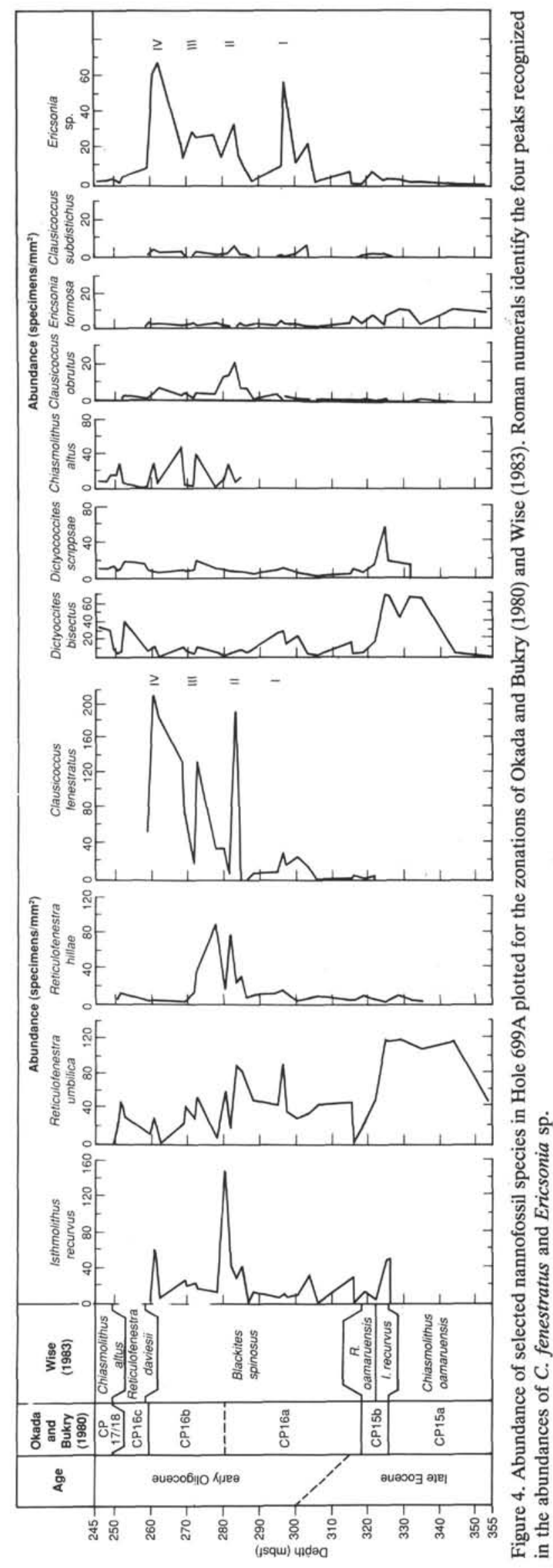




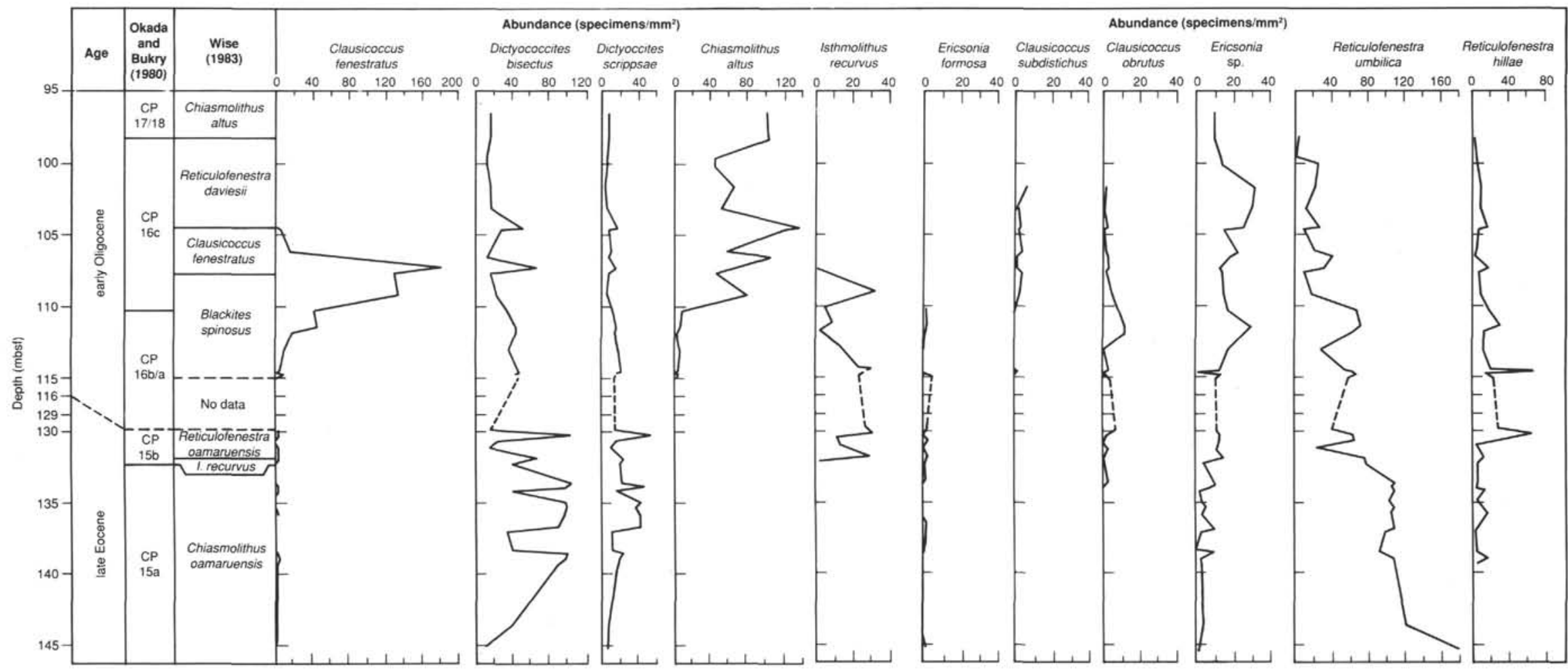

Figure 5. Abundance of selected nannofossil species in Hole 703A. 
dance of $D$. bisectus and $C$. altus. At Site $699 C$. obrutus and C. subdistichus are abundant and show several fluctuations. Four peaks are clearly recognizable in the lower Oligocene: (1) at about $300 \mathrm{mbsf}$; (2) at $280 \mathrm{mbsf}$, coincident with the peak of 1 . recurvus; (3) $10 \mathrm{~m}$ above at a depth of $270 \mathrm{mbsf}$; and (4) the largest peak at about 261 mbsf. At Site 703 the peaks of Ericsonia spp. and C. fenestratus are not so clear. The only detectable peak is that of $C$. fenestratus at a depth of about 107 mbsf (the extinction level of $I$. recurvus), which could be related to the last peak at Site 699 .

In the abundance plots of Figures 4 and 5, C. altus includes only specimens with a well-recognized central area; the chiasmolith rims without a central area are lumped in Chiasmolithus sp. $C$. altus shows high abundances from its FO high into the section studied.

It is notable that $C$. fenestratus, a form very rare and discontinuously present in the upper Eocene, shows a sharp increase in abundance at the first occurrence of $C$. altus and continues with high abundance up to its extinction level. It was noted at Site 699 that in the same interval where the FO of $C$. altus was found, I. recurvus, R. umbilica, and Ericsonia spp. show a sharp increase in abundance. At Site $703 C$. fenestratus and $C$. altus show a sharp increase in abundance in the upper part of the section.

\section{EOCENE/OLIGOCENE BOUNDARY}

The Eocene/Oligocene boundary is usually defined by planktonic foraminifers, by the extinction of Hantkenina, as equated by Nocchi et al. (1988) to the boundary between planktonic foraminiferal Zones P17 and P18 (Blow, 1969). The Eocene/Oligocene boundary could not be placed by planktonic foraminifers at the two studied sites because of drilling disturbances, incomplete recovery at Site 703, and the strong dissolution of planktonic foraminifers in the upper Eocene and lower Oligocene sediments at Site 699 (Nocchi et al., this volume).

On the other hand, the Eocene/Oligocene boundary, in terms of calcareous nannofossils, is usually taken at low latitude at the top of Zones CP15 and/or NP20 by the LO of Discoaster barbadiensis and Discoaster saipanensis. From several studies of low-latitude sections in Italy and Spain, it was observed that the extinction of disc-shaped discoasters is coeval with the extinction of Globigerinatheka index (Nocchi et al., 1986, 1988; Monechi, 1986). Moreover, it slightly predates the Eocene/Oligocene boundary defined by planktonic foraminifers, the extinction level of Hantkenina and Cribrohantkenina.

In the Gubbio area the Eocene/Oligocene boundary, as far as the magnetostratigraphic correlation is concerned, occurs at the youngest polarity change within the reversed interval between Chrons 15 and 13. At high latitude the LO of $G$. index is best used to approximate the Eocene/Oligocene boundary. At Sites 703 and 699 it was very difficult to use this species. At Site $699 G$. index disappeared earlier as a result of strong dissolution at the top of Core 114-699A-37X, and at Site 703 the LO of $G$. index occurred at the top of Core 114-703A-15H because no samples were available from Core 114-703A-14H. Thus, the Eocene/Oligocene boundary is even more difficult to recognize using calcareous nannofossils. The extinction of the disc-shaped discoasters is not very reliable, because these taxa are known to survive longer in tropical areas in comparison to the low to middle latitudes and are absent at high latitude. Discoasters are common in warm water/low latitude, but are rare or absent in cold water/high latitude. At Site 703 $D$. barbadiensis and D. saipanensis are absent, whereas at Site 699 the few specimens discontinuously present disappear at Sample 114-699A-35X-3, 66-70 cm. Unfortunately, the reliability of this event is very low.

Detailed quantitative analyses performed at the Eocene/ Oligocene boundary in the Umbrian sequences and at the South Atlantic sites show that the boundary may be recognized by the sharp increase in abundance of Clausicoccus obrutus/Clausicoccus subdistichus (Monechi, 1986; Backman, 1987) and, possibly, by a marked change in proportion between Reticulofenestra umbilica and Ericsonia formosa. Because of preservation problems at Site 699, C. obrutus and $C$. subdistichus are quite rare and all the small Ericsonia-Clausicoccus were grouped in Ericsonia spp. The abundance pattern of Ericsonia spp. shows several fluctuations, and the first sharp increase is at about 300 mbsf. A marked change in abundance in $R$. umbilica is detectable at about 315 mbsf. These two events possibly represent the Eocene/Oligocene boundary between 315 and 300 mbsf.

At Site 703 the Eocene/Oligocene boundary is difficult to place because of the absence of disc-shaped discoasters and the lack of recovery from Core 114-703A-14H between 129 and 117 mbsf. The paleomagnetic data from Clement and Hailwood (this volume) suggest that the Eocene/Oligocene boundary can be placed in the lowermost reversed interval of Chron 13, coincident with the decrease in abundance of $R$. umbilica and the increase in abundance of $C$. obrutus at 130 mbsf.

\section{SUMMARY AND CONCLUSIONS}

In this paper we have described the calcareous nannofossil assemblages from the upper Eocene and lower Oligocene section of high-latitude Sites 699 and 703. Several biostratigraphic events were recognized and correlated between the two sites, although some discrepancies exist in the succession of events and in the assemblages. Site 703 is characterized by the presence of species absent at Site 699, namely Zygrhablithus bijugatus (a holococcolith commonly preserved in water depths less than $1000 \mathrm{~m}$; Edwards and Perch-Nielsen, 1975), Bramletteius serraculoides (warm-water taxa; Bukry, 1972) in the Eocene interval, Sphenolithus moriformis (a cosmopolitan form, not very abundant here), rare pontosphaerids (well known to prefer nearshore environments), and Thoracosphaera saxea common in the upper Eocene. Discshaped discoasters and warm-water taxa are absent. The LO of Cribrocentrum reticulatum (a warm-water taxon) occurs later at Site 703 than at Site 699, where it disappears before the LO of Isthmolithus recurvus. In the nannofloral assemblage at Site 699 Discoaster barbadiensis, Discoaster saipanensis, $S$. moriformis, B. serraculoides, and $T$. saxea are present in scarce amounts and $Z$. bijugatus, Neococcolithes dubius, and the pontosphaerids are absent.

The differences in the calcareous nannofossil assemblages between the two holes in the upper Eocene interval may suggest warmer water conditions at Site 703 than at Site 699. During the early Oligocene the climatic conditions seemed more uniform, and the differences between the two holes are fewer. The Oligocene assemblage is characterized mainly by cool-water taxa and the diversity (number of species) is very low, with no more than 12 taxa.

Correlation with the magnetostratigraphy at Site 703 reveals some biostratigraphic discrepancies in the exit and entry of Isthmolithus recurvus. Crux (this volume) found rare $I$. recurvus lower, in Sample 114-703A-15H-CC, suggesting rare and sporadic occurrences within Chron $\mathrm{C} 16 \mathrm{~N}(\sim 38-27 \mathrm{Ma})$, The first appearance of this species is in the lower part of $\mathrm{CR} 15 \mathrm{~N}$, leading to a younger estimate than previously reported. Monechi (1986) reported this event in the Gubbio area at the very top of Chron 16, whereas Lowrie et al. (1982) 
bserved this event within Chron $15 \mathrm{~N}$ from another section in 1e Gubbio area; Backman (1987) observed the same event at ite 523 immediately above Chron 17. In conclusion, the iostratigraphic value of $I$. recurvus seems to yield a very low sliability.

The Eocene/Oligocene boundary could not be placed preisely mainly because of poor sediment recovery. Neverthess, its possible placement was determined within a narrow iterval.

\section{ACKNOWLEDGMENTS}

We would like to thank Sherwood Wise and Wuchang Wei or the helpful criticism and critical reading of the manuscript. Ve are also most grateful to Jason Crux, Jackie Burnett, and Uarisa Nocchi for providing several samples from Sites 699 nd 703. Mr. Francesco Landucci prepared the samples, Mr. 'abio Cozzini printed the microphotographs, and Dr. Viviana ieale helped type the manuscript.

\section{REFERENCES}

lackman, J., 1986. Accumulation patterns of Tertiary calcareous nannofossils around extinctions. Geol. Rundsch., 75:185-196. 1987. Quantitative calcareous nannofossil biochronology of middle Eocene through early Oligocene sediment from DSDP Sites 522 and 523. Abh. Geol. Bundensanst. Austria, 39:21-31.

3ackman, J., and Shackleton, N. J., 1983. Quantitative biochronology of Pliocene and early Pleistocene calcareous nannofossils from the Atlantic, Indian and Pacific oceans. Mar. Micropaleontol., 8:141-170

3low, W. H., 1969. Late middle Eocene to Recent planktonic foraminiferal biostratigraphy. In Brönnimann, P., and Renz, H. H. (Eds.), Proc. Intern. Conf. Planktonic Microfossils, 1:199-422.

3oersma, A., Premoli Silva, I., and Shackleton, N. J., 1987. Atlantic Eocene planktonic foraminiferal paleohydrographic indicators and stable isotope paleoceanography. Paleoceanography, 2:287-331.

3ukry, D., 1972. Further comments on coccolith stratigraphy, Leg 12, DSDP. In Laughton, A. S., Berggren, W. A., et al., Init. Repts. DSDP, 12: Washington (U.S. Govt. Printing Office), 1071-1083. 1973. Low-latitude coccolith biostratigraphic zonation. In Edgar, N. T., Saunders, J. B., et al., Init. Repts. DSDP, 15: Washington (U.S. Govt. Printing Office), 685-704. , 1975. Coccolith and silicoflagellate stratigraphy, northwestern Pacific Ocean, DSDP, Leg 63. In Larson, R. L., Moberly, R., et al., Init. Repts. DSDP, 32: Washington (U.S. Govt. Printing Office), 677-701.

1977. Cenozoic coccolith and silicoflagellate stratigraphy, offshore northwest Africa, DSDP Leg 41. In Lancelot, Y., Seibold, E., et al., Init. Repts. DSDP, 41: Washington (U.S. Govt. Printing Office), 689-719.

Ziesielski, P. F., Kristoffersen, Y., et al., 1988. Proc. ODP, Init. Repts., 114: College Station, TX (Ocean Drilling Program).

Joccioni, R., Monaco, P., Monechi, S., Nocchi, M., and Parisi, G., 1988. Biostratigraphy of the Eocene-Oligocene boundary at Massignano (Ancona, Italy). In Premoli Silva, I., Coccioni, R., and Montanari, A., Int. Subcomm. Paleog. Strat., Eocene/Oligocene Meeting, Spec. Publ., II, 1:59-80.

Edwards, A. R., and Perch-Nielsen, K., 1975. Calcareous nannofossils from the southern Southwest Pacific, DSDP Leg 29. In Kennett, J. P., Houtz, R. E., et al., Init. Repts. DSDP, 29: Washington (U.S. Govt. Printing Office), 469-539.

Haq, B. U., Lohmann, G. P., and Wise, S. W., 1977. Calcareous nannoplankton biogeography and its paleoclimatic implications: Cenozoic of the Falkland Plateau (DSDP Leg 36) and Miocene of the Atlantic Ocean. In Barker, P. F., Dalziel, I.W.D., et al., Init. Repts. DSDP, 36: Washington (U.S. Govt. Printing Office), 745760.

Keigwin, L. D., and Corliss, B. H., 1986. Stable isotope in the late middle Eocene to Oligocene Foraminifera. Geol. Soc. Am. Bull., 97:335-345.

Kennett, J. P., 1977. Cenozoic evolution of Antarctic glaciation, the circum-Antarctic Ocean, and their impact on global paleoceanography. J. Geophys. Res., 82:3843-3860.
1978. The development of planktonic biogeography in the Southern Ocean during the Cenozoic. Mar. Micropaleontol., 3:301-345.

Krasheninnikov, V. A., and Basov, I. A., 1986. Late Mesozoic and Cenozoic stratigraphy and geological history of the South Atlantic high latitudes. Palaeogeogr., Palaeoclimatol., Palaeoecol., 55:145-188.

Loeblich, A. R., and Tappan, H., 1966. Annotated index and bibliography of the calcareous nannoplankton. Phycologia, 5:81-216.

1968. Annotated index and bibliography of the calcareous nannoplankton II. J. Paleontol., 42:584-598.

1969. Annotated index and bibliography of the calcareous nannoplankton III. J. Paleontol., 43:568-588.

1970a. Annotated index and bibliography of the calcareous nannoplankton IV. J. Paleontol., 44:558-574.

1970b. Annotated index and bibliography of the calcareous nannoplankton V. Phycologia, 9:157-174.

1971. Annotated index and bibliography of the calcareous nannoplankton VI. Phycologia, 10:315-339. 1973. Annotated index and bibliography of the calcareous nannoplankton VII. J. Paleontol., 47:715-759.

Lowrie, W., Alvarez, W., Napoleone, G., Perch-Nielsen, K., Premoli Silva, I., and Toumarkine, M., 1982. Paleogene magnetic stratigraphy in Umbrian pelagic carbonate rocks: the Contessa sections, Gubbio. Geol. Soc. Am. Bull., 93:414-432.

Martini, E., 1971. Standard Tertiary and Quaternary calcareous nannoplankton zonation. In Farinacci, A. (Ed.), Proc. 2nd Planktonic Conf. Roma, 1971, 2:739-785.

Monechi, S., 1986. Calcareous nannofossil events around the EoceneOligocene boundary in the Umbrian Apennines (Italy). Palaeogeogr., Palaeoclimatol., Palaeoecol., 57:61-70.

Moshkovitz, S., 1974. A new method for observing the same nannofossil specimen both by light microscope and scanning electron microscope and preservation of types. Isr. J. Earth-Sci., 23:145147.

Nocchi, M., Parisi, G., Monaco, P., Monechi, S., Madile, M., Napoleone, G., Ripepe, M., Orlando, M., Premoli Silva, I., and Rice, D. M., 1986. The Eocene-Oligocene boundary in the Umbrian pelagic sequences (Italy). In Pomerol, C., and Premoli Silva, I. (Eds.), Terminal Eocene Events: New York (Elsevier), $25-41$.

Nocchi, M., Monechi, S., Coccioni, R., Madile, M., Monaco, P., Orlando, M., Parisi, G., and Premoli Silva, I., 1988. The extinction of HANTKENINIDAE as a marker for recognizing the EoceneOligocene boundary: a proposal. In Nocchi, M., et al. (Eds.), Int. Subcomm. Paleog. Strat., Eocene/Oligocene Meeting, Spec. Publ., 1:249-252.

Okada, H., and Bukry, D., 1980. Supplementary modification and introduction of code numbers to the low-latitude coccolith biostratigraphy zonation (Bukry, 1973; 1975). Mar. Micropaleontol., 5:321-325.

Premoli Silva, I., Orlando, M., Monechi, S., Madile, M., Napoleone, G., and Ripepe, M., 1988. Calcareous plankton biostratigraphy and magnetostratigraphy at the Eocene-Oligocene transition in the Gubbio area. In Premoli Silva, I., Coccioni, R., and Montanari, A., Int. Subcomm. Paleog. Strat., EocenelOligocene Meeting, Ancona, Oct. 1987 Spec. Publ., II, 6:137-161.

Shafik, S., 1981. Nannofossil biostratigraphy of the Hantkenina (foraminiferid) interval in the upper Eocene of southern Australia. BMR J. Aust. Geol. Geophys., 6:108-116.

Siesser, W. G., 1975. Calcareous nannofossils from South African continental margin. Mar. Geol. Prog., 5:1-135.

Steinmetz, J. C., 1985a. Bibliography and taxa of calcareous nannoplankton - V. INA Newsl., 7:5-28.

1985b. Bibliography and taxa of calcareous nannoplankton - VI. INA Newsl., 7:122-145.

1986a. Bibliography and taxa of calcareous nannoplankton - VII. INA Newsl., 8:12-32.

1986b. Bibliography and taxa of calcareous nannoplankton - VIII. INA Newsl., 8:66-87.

1987a. Bibliography and taxa of calcareous nannoplankton - IX. INA Newsl., 9:6-29.

1987b. Bibliography and taxa of calcareous nannoplankton - X. INA Newsl., 9:81-109. 
van Heck, S. E., 1979a. Bibliography and taxa of calcareous nannoplankton. INA Newsl., 1:AB1-B27.

,1979b. Bibliography and taxa of calcareous nannoplankton. INA Newsl., 1:ABV1-B42.

1980a. Bibliography and taxa of calcareous nannoplankton. INA Newsl., 2:5-34.

1980b. Bibliography and taxa of calcareous nannoplankton. INA Newsl., 2:43-81.

1981a. Bibliography and taxa of calcareous nannoplankton. INA Newsl., 3:4-41.

1981b. Bibliography and taxa of calcareous nannoplankton. INA Newsl., 3:51-86.

1982a. Bibliography and taxa of calcareous nannoplankton. INA Newsl., 4:7-50.

1982b. Bibliography and taxa of calcareous nannoplankton. INA Newsl., 4:65-96.

Wei, W., and Wise, S. W., Jr., in press. Middle Eocene through Pleistocene calcareous nannofossils recovered by ODP Leg 113 in the Weddell Sea. In Barker, P. F., Kennett, J. P., et al., Proc. ODP, Sci. Results, 113: College Station, TX (Ocean Drilling Program).

Wise, S. W., 1983. Mesozoic and Cenozoic calcareous nannofossils recovered by Deep Sea Drilling Project Leg 71 in the Falkland Plateau region, southwest Atlantic Ocean. In Ludwig, W. J., Krasheninnikov, V. A., et al., Init. Repts. DSDP, 71: Washington (U.S. Govt. Printing Office), 481-550.

Wise, S. W., Ciesielski, P. F., MacKenzie, D. T., Wind, F. H., Busen, K. E., Gombos, A. M., Haq, B. U., Lohmann, G. P., Tjalsma, R. C., Hanis, W. K., Hedlund, R. W., Beju, D. N., Jones, D. L., Plafker, G., and Sliter, W. V., 1982. Paleontologic and paleoenvironmental synthesis for the southwest Atlantic Ocean basin based on Jurassic to Holocene faunas and floras from the Falkland Plateau. In Craddock, C. (Ed.), Antarctic Geoscience: Madison (Univ. Wisconsin Press), 155-163.

Wise, S. W., and Mostajo, E. L., 1983. Correlation of EoceneOligocene calcareous nannofossil assemblages from piston cores taken near DSDP Sites 511 and 512 southwest Atlantic Ocean. In Ludwig, W. J., Krasheninnikov, V. A., et al., Init. Repts. DSDP, 71: Washington (U.S. Govt. Printing Office), 1171-1180.

Wise, S. W., and Wind, F. H., 1977. Mesozoic and Cenozoic calcareous nannofossils recovered by DSDP Leg 36 drilling on the Falkland Plateau, southwest Atlantic sector of the Southern Ocean. In Barker, P., Dalziel, I.W.D., et al., Init. Repts. DSDP, 36: Washington (U.S. Govt. Printing Office), 269-492.

Date of initial receipt: 24 April 1989

Date of acceptance: 3 January 1990 Ms 114B-185

\section{APPENDIX}

Calcareous Nannofossils in Alphabetical Order of Species Epithets

Cyclicargolithus abisectus (Müller, 1970) Wise, 1973

Chiasmolithus altus Bukry and Percival, 1971

Discoaster barbadiensis Tan, 1927

Zygrhablithus bijugatus (Deflandre in Deflandre and Fert, 1954) Deflandre, 1959

Dictyococcites bisectus (Hay, Mohler, and Wade, 1966) Bukry and Percival, 1971

Helicosphaera compacta (Bramlette and Sullivan, 1961) Hay and Mohler, 1967

Reticulofenestra daviesii (Haq, 1968) Haq, 1971

Discoaster deflandrei Bramlette and Riedel, 1954

Reticulofenestra $\mathrm{cf}$. $R$. dictyoda (Deflandre in Deflandre and Fert, 1954) Stradner, 1968

Neococcolithes dubius (Deflandre in Deflandre and Fert, 1954) Black, 1967

Coccolithus eopelagicus (Bramlette and Riedel, 1954) Bramlette and Sullivan, 1961

Clausicoccus fenestratus (Deflandre and Fert, 1954) Prins, 1979

Cyclicargolithus floridanus (Roth and Hay in Hay et al., 1967) Bukry, 1971

Ericsonia formosa (Kamptner, 1963) Haq, 1971

Reticulofenestra hillae Bukry and Percival, 1971

Calcidiscus kingii (Roth, 1970) Loeblich and Tappan, 1968

Pedinocyclus larvalis (Bukry and Bramlette, 1969) Loeblich and Tappan, 1973

Cyclicargolithus cf. C. marismontium (Black, 1964) Perch-Nielsen, 1985

Sphenolithus moriformis (Bronnimann and Stradner, 1960) Bramlette and Wilcoxon, 1967

Coronocyclus nitescens (Kamptner, 1963) Bramlette and Wilcoxon, 1967

Chiasmolithus oamaruensis (Deflandre in Deflandre and Fert, 1954) Hay, Mohler, and Wade, 1966

Reticulofenestra oamaruensis (Deflandre in Deflandre and Fert, 1954) Stradner and Edwards, 1968

Clausicoccus obrutus (Perch-Nielsen, 1971) Prins, 1979

Coccolithus pelagicus (Wallich, 1877) Schiller, 1930

Pontosphaera plana (Bramlette and Sullivan, 1961) Haq, 1971

Sphenolithus predistentus Bramlette and Wilcoxon, 1967

Isthmolithus recurvus Deflandre in Deflandre and Fert, 1954

Cribrocentrum reticulatum (Gartner and Smith, 1967) Perch-Nielsen, 1971

Discoaster saipanensis Bramlette and Riedel, 1954

Reticulofenestra samodurovii (Hay, Mohler, and Wade, 1966) Roth, 1970

Thoracosphaera saxea Stradner, 1961

Dictyococcites scrippsae Bukry and Percival, 1971

Bramletteius serraculoides Gartner, 1969

Blackites spinosus (Deflandre and Fert, 1954) Hay and Towe, 1962

Birkelundia staurion (Bramlette and Sullivan, 1961) Perch-Nielsen, 1971

Clausicoccus subdistichus (Roth and Hay in Hay et al., 1967) Prins, 1979

Discoaster tanii Bramlette and Riedel, 1954

Reticulofenestra umbilica (Levin, 1965) Martini and Rizkowski, 1968 

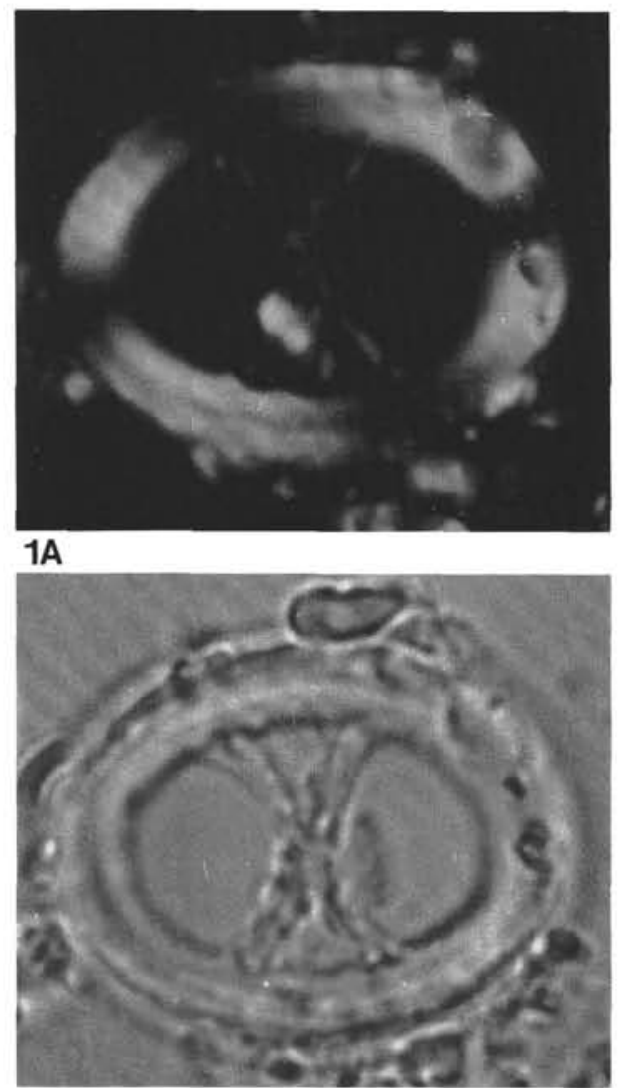

$1 B$

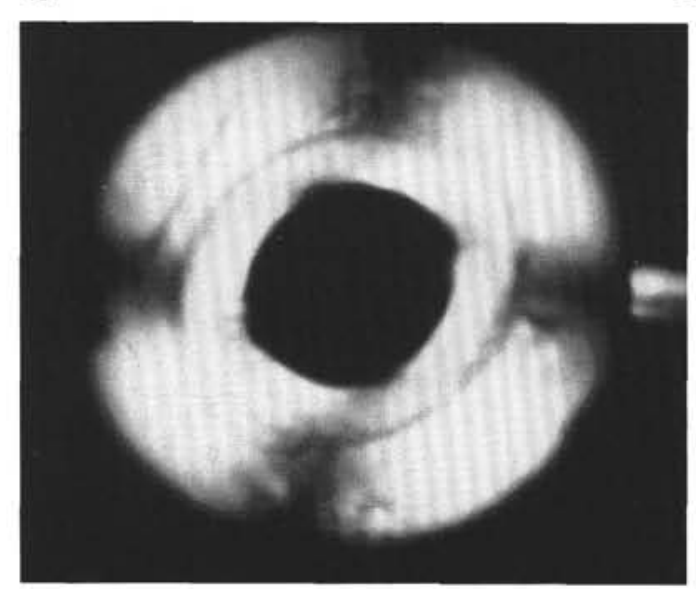

4A

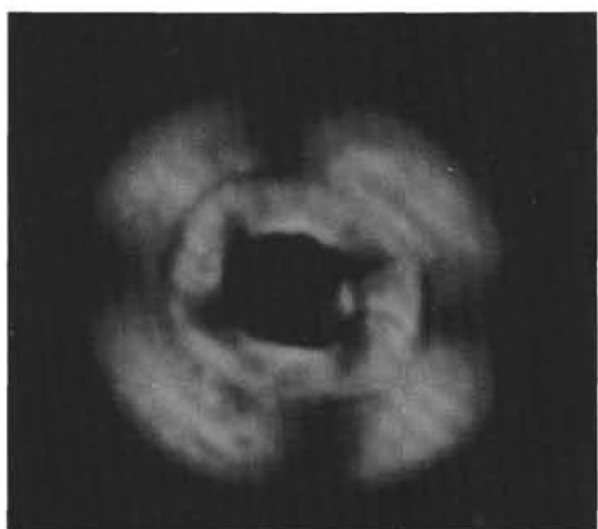

2A

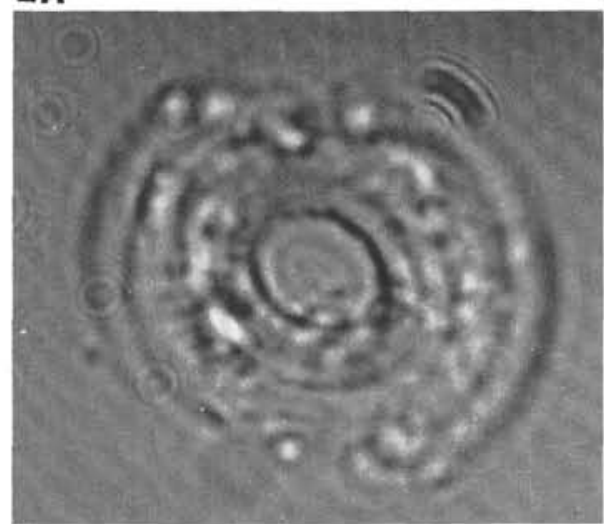

2B

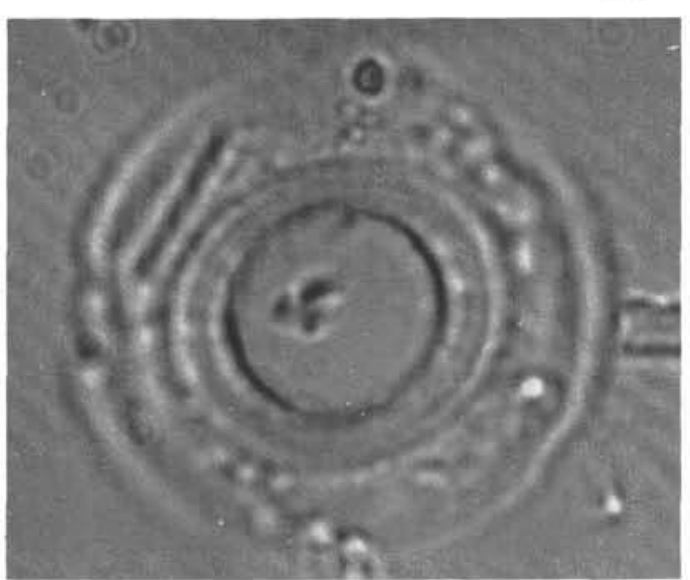

4B

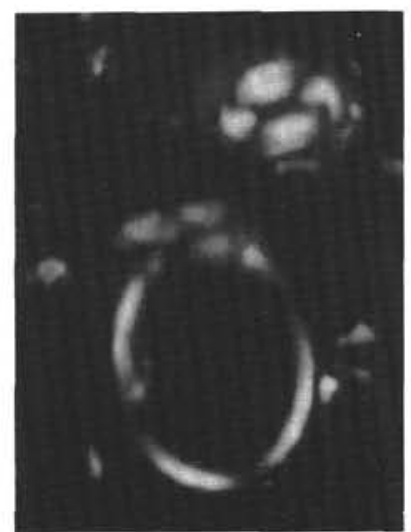

3A

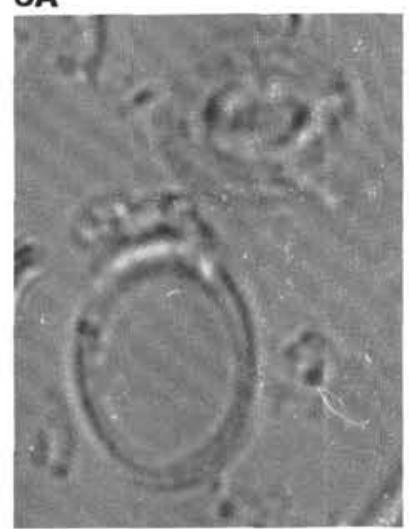

3B

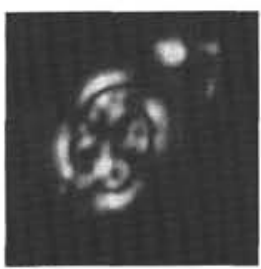

$5 \mathbf{A}$

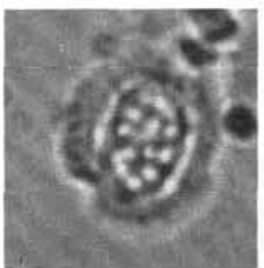

5B

$5 \mu \mathbf{m}$

Plate 1. For all figures: A. cross-polarized light and B. transmitted light. 1. Chiasmolithus oamaruensis; Sample 114-703A-15H-5, 40-41 $\mathrm{cm}$, upper Eocene. 2. Reticulofenestra hillae; Sample 114-703A-13H-4, 130-131 cm, lower Oligocene. 3. Reticulofenestra oamaruensis; Sample 114-703A-15H-2, 40-42 cm, upper Eocene. 4. Reticulofenestra umbilica; Sample 114-699A-29X-1, 59-60 cm, lower Oligocene. 5. Clausicoccus fenestratus; Sample 114-699A-31X-2, 135-136 cm, lower Oligocene. 


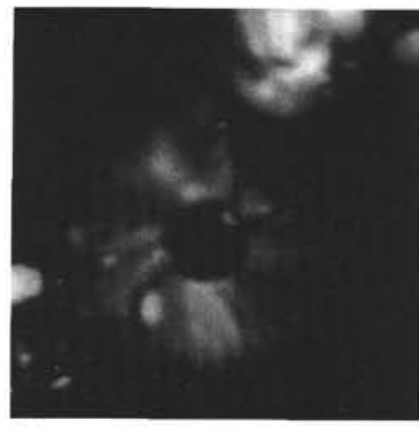

$1 \mathrm{~A}$

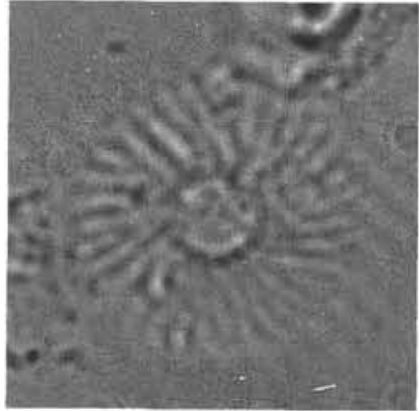

$1 B$

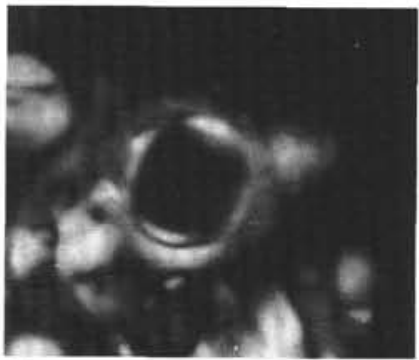

$5 \mathrm{~A}$

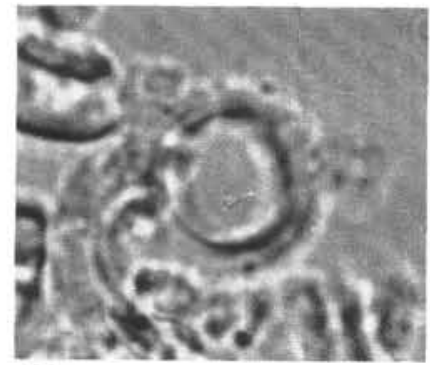

5B

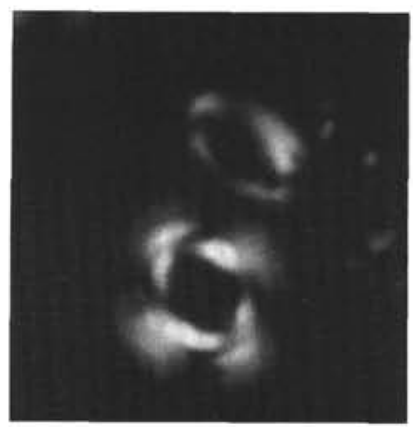

\section{A}

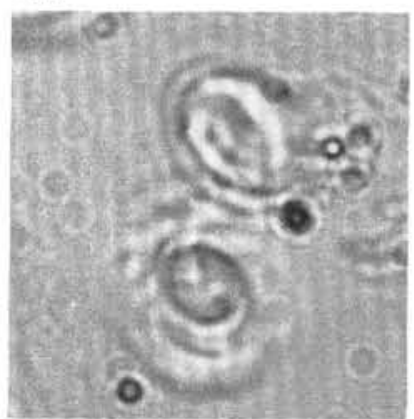

2B

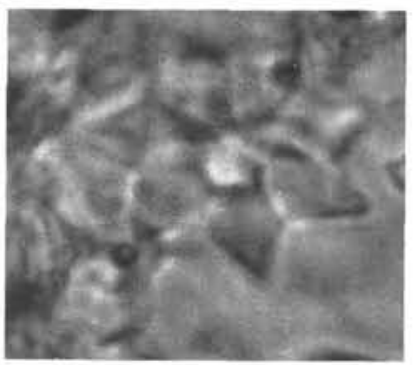

6

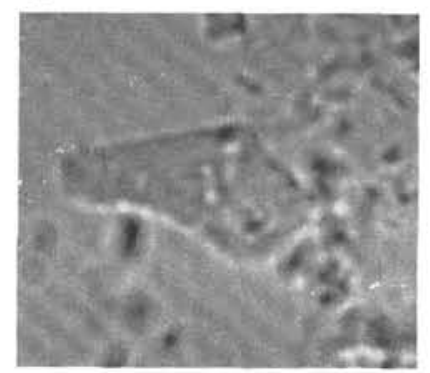

7

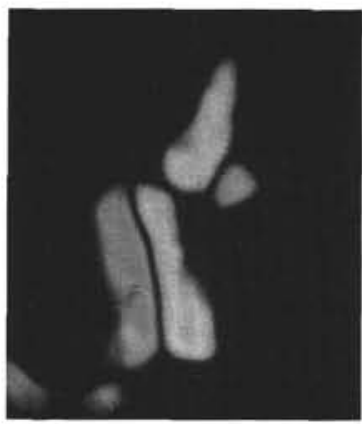

3A

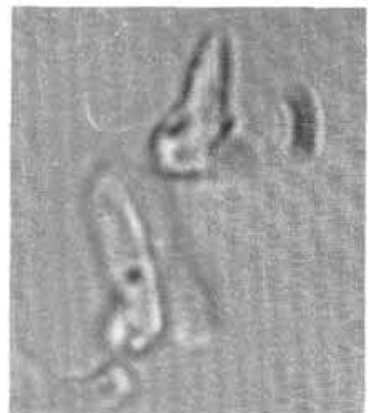

3B

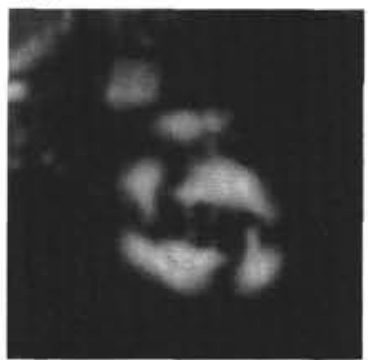

8A

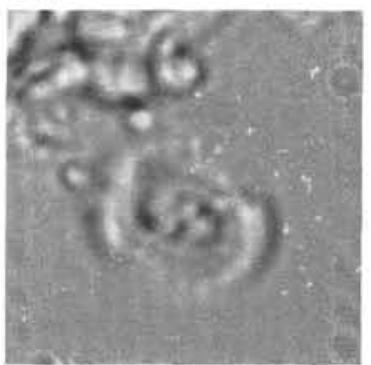

8B

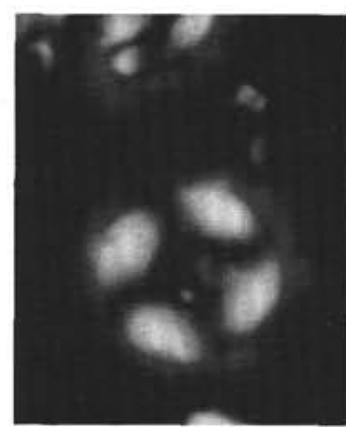

4A

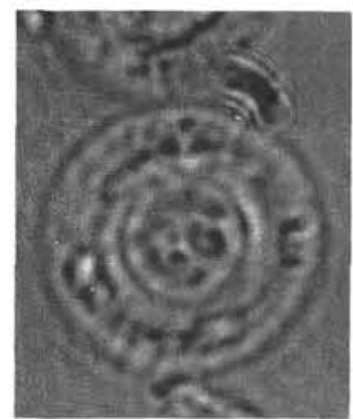

4B

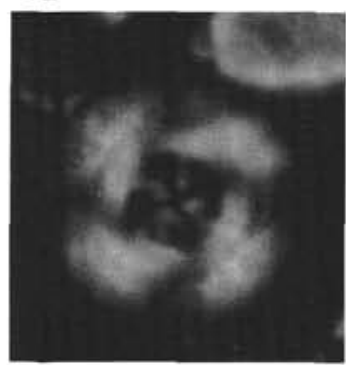

9A

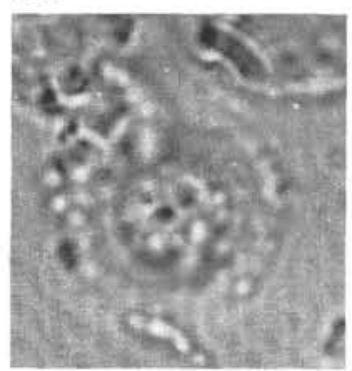

9B

$5 \mu \mathrm{m}$

Plate 2. For all figures: A. cross-polarized light and B. transmitted light. 1. Pedinocyclus larvalis; Sample 114-703A-13X-3, 34-35 cm, lower Oligocene. 2. Reticulofenestra cf. $R$. dictyoda; Sample 114-699A-31X-3, 138-139 cm, lower Oligocene. 3. Zygrhablithus bijugatus; Sample 114-703A-15H-4, 116-120 cm, upper Eocene. 4. Ericsonia formosa; Sample 114-703A-15H-3, 40-42 cm, upper Eocene. 5. Calcidiscus cf. C. kingii; Sample 114-703A-15H-2, 80-84 cm, upper Eocene. 6. Discoaster saipanensis; Sample 114-699A-36X-3, 135-136 cm, upper Eocene (transmitted light). 7. Bramletteius serraculoides; Sample 114-703A-15X-6, 95-96 cm, upper Eocene. 8. Reticulofenestra daviesii; Sample 114-703A-13H-4, 130-131 cm, lower Oligocene. 9. Cribrocentrum reticulatum; Sample 114-703A-15X-6, 95-96 cm, upper Eocene. 